\title{
KAJIAN POLA TANAM GANDA BERBASIS JAGUNG PADA LAHAN SAWAH TADAH HUJAN DI KABUPATEN GOWA PROVINSI SULAWESI SELATAN
}

\section{Study of Multiple Planting Patterns of Corn on Rainfed Fields in Gowa Regency, South Sulawesi}

\author{
Amir*1, Sarintang $^{1}$, Amiruddin Syam ${ }^{1}$, Syahruddin $^{2}$, dan Kawati ${ }^{2}$ \\ ${ }^{1}$ Balai Pengkajian Teknologi Pertanian Sulawesi Selatan \\ ${ }^{2}$ Universitas Tadulako dan Universitas Sulawesi Barat \\ *e-mail: amir_bio64@yahoo.com
}

Received: 12 September 2021; Accepted: 10 November 2021; Published: 25 Desember 2021

\begin{abstract}
ABSTRAK
Sulawesi Selatan memiliki lahan sawah tadah hujan seluas 228.605 ha sebagai potensi pengembangan jagung. Peningkatan produksi jagung pada lahan sawah tadah hujan dapat dilakukan melalui pola strip cropping dan pola monokultur. Strip cropping ialah menanam dua atau lebih jenis tanaman secara serentak pada lahan yang sama dalam luasan petak yang sama atau hampir sama antara tanaman utama dengan tanaman kedua dalam waktu satu tahun. Pola tanam ganda yang dikaji adalah jagung strip cropping kacang tanah, jagung strip cropping kacang hijau, jagung strip cropping kedele dan jagung strip cropping ubi jalar. Kelayakan penerapan sistem tanam strip cropping dapat dilihat dari nilai Nisbah Kesetaraan Lahan (NKL) lebih dari 1 (satu) berarti menguntungkan. Jagung strip cropping kacang tanah memiliki nilai NKL tertinggi yaitu 1,38 dan jagung strip croping kacang hijau memiliki NKL terendah yaitu 0,75 . Tujuan pengkajian untuk melihat pengaruh pola tanam ganda berbasis jagung terhadap produksi jagung strip cropping dan jagung monokultur, serta nilai Nisbah Kesetaraan Lahan pola monokultur dan pola strip cropping.
\end{abstract}

Kata kunci: Strip croping, monokultur, sawah tadah hujan

\begin{abstract}
South Sulawesi has 228,605 ha of rainfed rice fields as potential for maize development. Increasing corn production in rainfed lowland land can be done through strip cropping and monoculture patterns. Strip cropping is planting two or more types of plants simultaneously on the same land in the same or almost the same plot area between the main crop and the second crop within one year. The dual cropping patterns studied were strip cropping of peanuts, maize strip cropping of mung beans, strip cropping of soybeans and maize strip cropping of sweet potatoes. The feasibility of applying the strip cropping system can be seen from the Land Equivalence Ratio (NKL) value of more than 1 (one) means it is profitable. Peanut strip cropped corn had the highest NKL value of 1.38 and mung bean strip cropped corn had the lowest NKL of 0.75. The purpose of the study was to see the effect of a maize-based dual cropping pattern on the production of strip cropping and monoculture maize, as well as the value of the land equivalence ratio of monoculture and strip cropping patterns. Keywords: corn, peanuts, green beans, soybeans, sweet potatoes, strip cropping, monoculture, rainfed rice fields.
\end{abstract}

Keywords: Strip cropping, monoculture, rainfed rice fields 


\section{PENDAHULUAN}

Provinsi Sulawesi - Selatan termasuk salah satu sentra pengembangan jagung nasional di kawasan Timur Indonesia. Daerah ini memiliki agroekosistem lahan sawah tadah hujan seluas 228.605 ha (Badan Pusat Statistik, 2013) sebagai potensi pengembangan jagung. Jagung dapat dikembangkan (20-30 \%) pada agroekosistem lahan sawah tadah hujan (Kasryno, 2002).

Optimalisasi pemanfaatan lahan sawah tadah hujan di daerah ini dengan komoditas jagung masih tergolong rendah. Pada tahun 2009 produksi jagung di lahan sawah tadah hujan tercatat 1.395.742 ton dengan luas panen tercatat 299.669 hektar atau tingkat produktivitas 4,6 ton per hektar (BPS, 2010). Produktivitas tersebut masih jauh dibawah potensi hasil varietas unggul jagung yang berada pada level 9-11 ton per hektar (Adnan, et.al, 2010).

Data statistik menunjukkan bahwa di daerah ini masih terdapat sejumlah lahan sawah yang bera. Dalam musim tanam AprilSeptember, luasan lahan sawah yang bera tercatat 232.421 hektarar, dan dalam musim tanam Oktober-Maret, luas lahan sawah yang bera tercatat 167.000 hektar. Dengan demikian dalam dua musim tanam terdapat total luas lahan sawah yang bera 399.390 hektar (Fadhly dan Djamaluddin, 1993).

Pertumbuhan areal tanaman jagung pada musim kemarau lebih luas dibanding musim hujan (Subandi et.al, 1990). Sehingga pengembangan jagung kedepan akan lebih luas pada lahan sawah tadah hujan setelah padi dibanding pada lahan kering.

Air salah satu faktor pembatas pada agroekosistem lahan sawah tadah hujan. Sehingga petani sebagian memanfaatkan lahan sawah tadah hujan hanya satu kali padi kemudian bero, sebagian mengusahakan sumur pantek atau sumur bor di sudut sawah sebagai sumber air pengairan sehingga dapat ditanami lebih dari satu kali. Usahatani pada lahan sawah tadah hujan perlu dioptimalkan karena luasan lahan ini semakin berkurang akibat adanya perubahan fungsi lahan. Alih fungsi lahan sawah tadah hujan di Sulawesi Selatan pada tahun 2008 tercatat 16.526 hektar (BPS, 2010). Guna meningkatkan produksi pangan pada lahan sawah tadah hujan, perlu diupayakan pola tanam ganda berbasis komoditas unggulan daerah.
Jagung salah satu komoditas unggulan daerah Kabupaten Gowa sehingga dalam penerapan pola tanam ganda dipilih jagung sebagai basis komoditas. Tumpangsari adalah pertanaman dua jenis atau lebih tanaman secara serempak pada lahan yang sama dalam satu tahun (Beets, 1982). Strip cropping merupakan model pertanaman ganda dengan luasan petak yang sama atau hampir sama antara tanaman utama dengan tanaman kedua.

Pola tanam ganda yang diterapkan adalah jagung strip cropping kacang tanah, jagung strip cropping kacang hijau, jagung strip cropping kedele dan jagung strip cropping ubi jalar. Sistem tanam tumpangsari serealia dengan legum yang biasa digunakan petani tidak selalu memberikan hasil yang baik akibat pemilihan varietas yang tidak sesuai (Belel et.al, 2014).

Sistem tumpangsari jagung dengan kacang-kacangan meningkatkan efesiensi pemanfaatan sumber daya lahan, meningkatkan volume dan frekwensi panen dibanding sistem tanam monokultur (Syafruddin et.al, 2010). Sistem tanam tumpangsari lebih menguntungkan dari sistem tanam monokultur karena produktivias lahan menjadi lebih tinggi, jenis komoditas beragam, hemat pemakaian sarana produksi, resiko kegagalan lebih kecil, dan kesuburan tanah lebih terjamin (Beets, 1982 Dalam Syafruddin dan Suwardi, 2015).

Keuntungan penerapan sistem tanam tumpangsari/strip cropping dapat dilihat dari nilai Nisbah Kesetaraan Lahan (NKL). Nisbah Kesetaraan Lahan lebih dari 1 (satu) berarti sistem tanam tumpangsari menguntungkan (Yuwariah, 2011). Nisbah Kesetaraan Lahan atau dengan isltilah lain Land Equivalent Ratio (LER) adalah ukuran luas relatif lahan yang diperlukan untuk ditanami total produksi monokultur agar memberikan hasil yang setara satu hektar produksii tumpangsari. Keuntungan pola tumpangsari dibanding pola monokultur karena pada tumpangsari/strip cropping penggunaan sumber daya meningkat baik dalam ruang maupun waktu (Gliesman, 1985; Trenbath, 1986). Tujuan pengkajian ini untuk melihat pengaruh pola tanam ganda berbasis jagung terhadap produksi jagung dan produksi tanaman strip cropping serta nilai Nisbah Kesetaraan Lahan pola tanam strip cropping dan pola tanam monokultur. 


\section{METODE PENELITIAN}

Pengkajian dilaksanakan pada lahan sawah tadah hujan milik petani pada kelompok tani A'bulo Sibatang, desa Bonto Ramba, Kecamatan Bonto Nompo Selatan, Kabupaten Gowa Provinsi Sulawesi Selatan dari bulan Maret sampai Juli 2020.

Alat dan bahan yang digunakan yaitu: tugal, tali jarak tanam, pupuk organik dan anorganik, benih (jagung, kacang tanah, kacang hijau, kedele) dan stek ubi jalar serta bahan pendukung lainnya.

Pengkajian disusun menurut rancangan acak kelompok (RAK), empat ulangan dan lima pola tanam sebagai perlakuan. Ukuran plot perlakuan jagung monokultur (kontrol) 18,3m x $5 \mathrm{~m}$ sedang jagung strip cropping kacangan, ukuran plot jagung $(15,3 \mathrm{~m} \times 5 \mathrm{~m})$ dan kacangan ( $3 \mathrm{~m} \times 5 \mathrm{~m})$. Varietas jagung yang ditanam ialah HJ-37 dan kedele varietas Devon, sedang kacang hijau dan ubi jalar adalah varietas lokal yang umum ditanam petani. Jumlah biji jagung per lubang tanam, kacang tanah, kacang hijau dan kedele ialah 2 biji dan ubi jalar satu stek per lubang tanam. Ubi jalar dibuatkan guludan tanam dengan lebar guludan $100 \mathrm{~cm}$ dan tinggi guludan $30 \mathrm{~cm}$ serta jarak tanam $50 \mathrm{~cm} \times 30 \mathrm{~cm}$.

Pemupukan anorganik dilakukan dua kali untuk tanaman jagung yaitu umur tanaman 10 dan 35 (Hari Setelah Tanam), sedang pemupukan organik dilakukan satu kali pada saat tanam sebagai penutup lubang tanam. Jenis dan dosis pupuk per hektar yang digunakan untuk jagung yaitu: $400 \mathrm{~kg}$ NPK (16:16:16); 124,2 kg $\mathrm{N} ; 36,8 \mathrm{~kg} \mathrm{P} ; 25 \mathrm{~kg} \mathrm{~K}$ dan 2 ton pupuk organik. Dosis pemupukan pertama $50 \%$ NPK, $40 \% \mathrm{~N}$, $100 \% \mathrm{P}_{2} \mathrm{O}_{5}$ dan $0 \% \mathrm{~K}_{2} \mathrm{O}$ dan dosis pemupukan kedua: $50 \% \mathrm{NPK} ; 60 \% \mathrm{~N} ; \quad 0 \% \mathrm{P}_{2} \mathrm{O}_{5}$ dan $100 \%$ $\mathrm{K}_{2} \mathrm{O}$. Pupuk anorganik diberikan dengan cara ditugal sekitar 7-10 $\mathrm{cm}$ disamping tanaman jagung. Jenis dan dosis pupuk anorganik yang digunakan untuk pemupukam pertama dan kedua setiap komoditas (Tabel 2).

Tabel 1. Jarak tanam yang digunakan dalam pengkajian

\begin{tabular}{|c|c|c|c|c|}
\hline \multirow[b]{2}{*}{ Perlakuan } & \multicolumn{2}{|c|}{ Jarak Tanam } & \multicolumn{2}{|c|}{ Populasi tanaman/ha } \\
\hline & Jagung & Strip croping & Jagung & Tanaman strip \\
\hline A & $75 \mathrm{~cm} \times 40 \mathrm{~cm}$ & $40 \mathrm{~cm} \times 20 \mathrm{~cm}$ & 66.667 & 250.000 \\
\hline B & $75 \mathrm{~cm} \times 40 \mathrm{~cm}$ & $40 \mathrm{~cm} \times 20 \mathrm{~cm}$ & 66.667 & 250.000 \\
\hline $\mathrm{C}$ & $75 \mathrm{~cm} \times 40 \mathrm{~cm}$ & $40 \mathrm{~cm} \times 20 \mathrm{~cm}$ & 66.667 & 250.000 \\
\hline D & $75 \mathrm{~cm} \times 40 \mathrm{~cm}$ & $50 \mathrm{~cm} \times 30 \mathrm{~cm}$ & 66.667 & 66.666 \\
\hline $\mathrm{E}$ & $75 \mathrm{~cm} \mathrm{x} 40 \mathrm{~cm}$ & - & 66.667 & - \\
\hline
\end{tabular}

Keterangan: A). Jagung srip croping kacang tanah, B). Jagung strip croping kacang hijau, C). Jagung strip croping kedele, D). Jagung strip croping ubi jalar, E). Jagung monokultur (kontrol)

Tabel 2. Jenis dan dosis pupuk anorganik yang digunakan setiap komoditas

\begin{tabular}{lcccccccc}
\hline \multirow{3}{*}{ Strip croping } & \multicolumn{3}{c}{ Dosis Pupuk I/HA } & \multicolumn{3}{c}{ Dosis Pupuk II/HA } \\
\cline { 2 - 9 } & $\begin{array}{c}\mathrm{NPK} \\
(16: 16: 16)\end{array}$ & $\begin{array}{c}\mathrm{N} \\
(\mathrm{kg})\end{array}$ & $\begin{array}{c}\mathrm{P} \\
(\mathrm{kg})\end{array}$ & $\begin{array}{c}\mathrm{K} \\
(\mathrm{kg})\end{array}$ & $\begin{array}{c}\mathrm{NPK} \\
(16: 16: 16)\end{array}$ & $\begin{array}{c}\mathrm{N} \\
(\mathrm{kg})\end{array}$ & $\begin{array}{c}\mathrm{P} \\
(\mathrm{kg})\end{array}$ & $\begin{array}{c}\mathrm{K} \\
(\mathrm{kg})\end{array}$ \\
\hline Jagung & 200 & 49,7 & 36,8 & 0 & 200 & 74,5 & 0 & 25 \\
Kacang Tanah & 10 & 4,6 & 23 & 15 & 15 & 6,9 & 0 & 25 \\
Kacang Hijau & 10 & 4,6 & 46 & 12,5 & 15 & 6,9 & 0 & 25 \\
Kacang Kedele & 10 & 4,6 & 23 & 9 & 15 & 6,9 & 0 & 25 \\
Ubi jalar & 50 & 15,2 & 46 & 16,5 & 50 & 30,8 & 0 & 33,5 \\
Kontrol & 200 & 103,5 & 0 & 0 & 0 & 103,5 & 0 & 0 \\
\hline
\end{tabular}

Pemupukan pertama dan kedua tanaman kacang tanah, kacang hijau dan kedele umur 7 dan 30 Hari Setelah Tanam (HST) dan ubi jalar umur 7 dan 45 HST. Lubang pupuk tanaman kacang tanah, kacang hijau, dan kedele dibuat diantara dua tanaman sekitar $10 \mathrm{~cm}$ dari tanaman.
Sedang pupuk ubi jalar diberikan disamping lubang tanam sejauh 7-10 cm.

Penyulaman tanaman yang tidak tumbuh dilakukan satu minggu setelah tanam. Bahan sulaman tanaman jagung ditanam dalam polyback kecil yang ditanam bersamaan tanaman 
pertama, sehingga tanaman sulaman seumur tanaman pertama. Sementara sulaman tanaman strip cropping (kacang tanah, kacang hijau dan kedele) dilakukan dalam bentuk benih. Sebelum benih jagung ditanam terlebih dahulu direndam air kurang lebih setengah jam, atau bisa juga benih tanpa direndam asal lahan diairi sebelum tanam, bila kondisi tanah becek setelah diairi istirahatkan terlebih dahulu 1-2 hari baru tanam.

Apabila benih jagung belum diberi perlakuan benih (seed treatment), sebaiknya diberi saromil dengan dosis 1 gram $/ \mathrm{kg}$ benih sebagai pengendali penyakit bulai. Sedang untuk benih kacang-kacangan sebelum tanam, diberi insektisida sevin atau furadan agar aman dari hama semut. Pengairan dilakukan pada saat kondisi tanaman kekeringan yang ditandai dengan mengeringnya tanah dan menggulungnya pinggiran daun tanaman jagung. Pengairan dilakukan sebanyak 3-4 kali hingga tanaman panen. Pengairan dilakukan secara pompanisasi dengan menggunakan sumur bor di pinggir lokasi.

Pengendalian gulma dilakukan secara kimiawi dengan menggunakan herbisida Calaris yang bersifat selektif. Untuk pengendalian hama penggerek tongkol dan batang diberi Furadan ke dalam pucuk tanaman sebanyak 2 gram pertanaman pada umur tanaman 40-45 HST.

\section{Parameter Pengamatan}

Parameter yang diamati adalah Tinggi tanaman jagung $(\mathrm{cm})$, Tinggi letek tongkol jagung $(\mathrm{cm})$, Umur anthesis jagung 50\% (hari),
Umur silking jagung 50\% (hari), Indeks Luas Daun (ILD), Jerami jagung (t/ha), Bobot 1000 biji (g), Jumlah butir per kg biji (butir), Produksi jagung strip cropping dan jagung monokultur, Produksi kacangan strip cropping dan kacangan monokultur, Produksi ubi jalar strip cropping dan ubi jalar monokultur, dan Nilai Kesetaraan Lahan (NKL)

\section{HASIL DAN PEMBAHASAN}

Data komponen pertumbuhan tiinggi tanaman dan tinggi letak tongkol serta umur tasseling dan umur silking tanaman jagung (Tabel 3). Lima perlakuan pola tanam yang dikaji tidak menunjukkan perbedaan nyata terhadap tinggi tanaman dan tinggggi letak tongkol serta umur tasseling dan umur silking jagung. Hal ini disebabkan kompetisi yang tejadi antara tanaman jagung dengan tanaman strip cropping tidak sampai batas kritis yang mempegaruhi pertumbuhan tanaman jagung. Tanaman strip cropping lebih pendek dari tanaman utama sehingga tidak mengurangi intensitas cahaya ke tanaman jagung sebagai tanaman $\mathrm{C} 4$. Persaingan dibawah tanah pun seperti hara dan air terjadi namun tidak sampai batas kritis tanaman karena diduga adanya perbedaan bentuk perakaran tanaman jagung dengan tanaman strip cropping.

Tinggi letak tongkol jagung berada pada tiga posisi yakni, di tengah batang, diatas tengah batang, dan dibawah tengah batang. Jagung hibrida varietas $\mathrm{HJ}-37$ posisi letak tongkol di tengah batang (Tabel 3).

Tabel 3. Pengaruh pola tanam ganda berbasis jagung terhadap t. tanaman dan t.letak tongkol serta umur tasseling dan umur silking jagung pada agroekosistem lahan sawah tadah hujan di Kab. Gowa

\begin{tabular}{ccccc}
\hline Perlakuan & $\begin{array}{c}\text { Tinggi Tan jagung } \\
(\mathrm{cm})\end{array}$ & $\begin{array}{c}\text { Tiinggi tkl jagung } \\
(\mathrm{cm})\end{array}$ & $\begin{array}{c}\text { Umur anthesis jagung } \\
50 \%(\text { hari })\end{array}$ & $\begin{array}{c}\text { Umur silking } \\
\text { jagung 50\% (hari) }\end{array}$ \\
\hline A & 218.97 & 119,62 & 48,75 & 52,25 \\
B & 220,87 & 116,87 & 48,75 & 52,75 \\
C & 228,95 & 121,05 & 48,25 & 52,75 \\
D & 220,85 & 125,37 & 48,50 & 53,00 \\
E & 220,47 & 118,60 & 48,75 & 53,00 \\
KK (\%) & 3,5 & 5,6 & 1,3 & 1,2 \\
\hline
\end{tabular}

Keterangan: A). Jagung strip croping kacang tanah, B). Jagung strip croping kacang hijau, C). Jagung strip cropping kedele, D). Jagung strip croping ubi jalar, E). Jagung monokultur (kontrol)

Informasi posisi letak tongkol suatu varietas jagung perlu sebagai alternatif suatu varietas dapat dikembangkan atau tidak pada ekosistem wilayah yang endemik hama anjing dan babi. Semua perlakuan pola tanam ganda yang dikaji tidak menunjukkan pengaruh nyata terhadap umur anthesis dan umur silking jagung (Tabel 3). Hal ini disebabkan varietas jagung 
yang ditanam hanya satu macam sehingga secara genetis sama terhadap umur anthesis dan umur silking. Disamping itu tanaman strip cropping dengan bentuk morfologi tanaman yang pendek tidak menghalangi

intensitas penyinaran matahari ketanaman jagung. Rataan umur anthesis jagung 50\% lebih cepat (48-49) hari dibanding umur silking 52-53 hari (Tabel 3). $\sqrt{ }$

Fase generatif atau pembungaan dimulai pada umur 60 hari setelah tanam dan membutuhkan waktu 2-3 hari untuk membuahi rambut dalam satu tongkol (Sri Sumarti, 2006). Perbedaan waktu yang lebih dari empat hari antara munculnya bunga jantan dan bunga betina diduga akan mempengaruhi optimalisasi penyerbukan jagung.

Perlakuan A (jagung strip cropping kacang tanah) memberikan kanopi daun jagung lebih rimbun dan berbeda nyata dengan perlakuan E terhadap Indeks Luas Daun (Tabel 4).

Tabel 4. Pengaruh pola tanam ganda berbasis jagung terhadap ild, jerami, bobot 1000 biji dan jumlah butir/kg biji jagung pada agroekosistem lahan sawah tadah hujan di Kab. Gowa

\begin{tabular}{ccccc}
\hline Perlakuan & $\begin{array}{c}\text { Indeks Luas } \\
\text { Jagung }\end{array}$ & $\begin{array}{c}\text { Jerami jagung } \\
(\mathrm{t} / \mathrm{ha})\end{array}$ & $\begin{array}{c}\text { Bobot } 1000 \text { biji jagung } \\
(\mathrm{g})\end{array}$ & $\begin{array}{c}\text { Jumlah butir/ kg } \\
\text { biji jagung }\end{array}$ \\
\hline A & 4,26 a & 12,37 & 291,17 & 3437,5 \\
B & 4,07 ab & 12,42 & 302,50 & 3313,0 \\
C & 4,14 ab & 12,45 & 305,62 & 3278,5 \\
D & 3,74 ab & 13,15 & 293,60 & 3413,3 \\
E & 3,56 b & 12,70 & 297,75 & 3360,8 \\
KK $(\%)$ & 10,3 & 10,6 & 4,2 & 4,3 \\
\hline
\end{tabular}

Keterangan: Huruf yang berbeda pada kolom yang sama menunjukkan berbeda nyata menurut Uji Berganda Duncan 5\%. A). Jagung strip cropping kacang tanah, B). Jagung strip cropping kacang hijau, C). Jagung strip cropping kedele, D). Jagung strip cropping ubi jalar, E). Jagung monokultur (kontrol)

Kanopi daun jagung yang lebar dan rimbun menyebabkan banyak daun tumpang tindih sehingga daun bagian bawah tidak produktif dalam fotosintesa. Semakin lebar daun tanaman jagung, semakin banyak daun yang tumpang tindih dan daun bagian bawah tidak mendapat sinar matahari secara optimal, sehingga mempengaruhi aktivitas fotosintesa tanaman yang berdampak terhadap produksi bahan kering tanaman sebagai bahan baku produksi biji (Fik dan Hanway, 1996 Dalam Amir et.al, 2015). Standar indeks luas daun jagung hibrida 3,3 - 4,0 (Stoskops, 1981 Dalam Effendi dan Suwardi, 2010).

Jerami jagung dapat dimanfaatkan sebagai pakan ternak, mulsa dan pupuk organik. Keuntungan pemanfaatan jerami jagung sebagai pakan ternak ruminansia, karena jerami jagung mengandung serat kasar 27,8\%; lemak 1,5\%; protein 7,4\%; abu 10,8 \% dan BETN 53,1\% (Amir, 2010).

Manfaat jerami sebagai mulsa organik terutama pada daerah tropika dapat menurunkan suhu tanah harian lebih rendah dibanding suhu tanah yang terbuka pada siang hari. Hal ini penting karena suhu tanah yang terbuka dan kering dapat mencapai $40{ }^{\circ} \mathrm{C}$ atau lebih yang mempengaruhi aktivitas perakaran tanaman (Harrison, Murray dan Lal, 1979). Lima pola tanam ganda berbasis jagung yang dikaji tidak menunjukkan pengaruh nyata terhadap bobot 1000 biji dan jumlah butir per kilogram biji jagung (Tabel 4). Hal ini diduga dosis pupuk yang digunakan dan varietas jagung yang ditanam sama, serta persaingan dibawah tanah antara tanaman utama dengan tanaman strip cropping tidak sampai mempengaruhi batas kritis tanaman sehingga tidak terjadi variasi pertumbuhan.

Bobot seribu biji dan jumlah butir per kilogram biji, umumnya ditentukan jumlah pupuk yang diberikan dan varietas jagung yang ditanam. Kedua faktor tersebut bila dikombinasi berbagai dosis pupuk pada beberapa varietas jagung akan menimbulkan variasi komponen pertumbuhan dan komponen hasil. Tanaman kacang tanah, kacang hijau, kacang kedele dan ubi jalar sebagai tanaman strip memberikan kompetisi yang tidak significant terhadap cahaya, hara dan air bagi tanaman jagung. Perlakuan pola tanam ganda berbasis jagung memberikan rerata bobot seribu biji jagung 291 - 305 gram dan 
rerata jumlah butir per kilogram biji jagung 3278 - 3437 butir (Tabel 4).

Strip cropping terdiri empat jenis tanaman, tiga tanaman kacangan dan satu tanaman ubi jalar serta jagung sebagai tanaman utama. Data menunjukkan perlakuan A jagung strip cropping kacang tanah memberikan nilai kesetaraan lahan terbesar yaitu 1,38 namun tidak berbeda nyata dengan perlakuan $\mathrm{D}$ (Tabel 5).

Tabel 5. Pengaruh pola tanam ganda berbasis jagung terhadap nilai kesetaraan lahan (NKL)

\begin{tabular}{|c|c|c|c|c|c|c|c|c|c|c|c|}
\hline \multirow{2}{*}{ Perlakuan } & \multicolumn{2}{|c|}{$\begin{array}{c}\text { Produksi } \\
\text { Jagung }\end{array}$} & \multicolumn{2}{|c|}{$\begin{array}{c}\text { Produksi } \\
\text { Kc. Tanah } \\
\end{array}$} & \multicolumn{2}{|c|}{$\begin{array}{l}\text { Produksi } \\
\text { Kc. Hijau }\end{array}$} & \multicolumn{2}{|c|}{$\begin{array}{c}\text { Produksi } \\
\text { Kedele }\end{array}$} & \multicolumn{2}{|c|}{$\begin{array}{l}\text { Produksi } \\
\text { Ubi Jalar }\end{array}$} & \multirow[t]{2}{*}{ NKL } \\
\hline & $\begin{array}{l}\text { mono } \\
\text { kultur }\end{array}$ & $\begin{array}{l}\text { strip. } \\
\text { croping }\end{array}$ & $\begin{array}{l}\text { mono } \\
\text { kultur }\end{array}$ & $\begin{array}{c}\text { strip } \\
\text { croping }\end{array}$ & $\begin{array}{l}\text { mono } \\
\text { kultur }\end{array}$ & $\begin{array}{l}\text { strip } \\
\text { croping }\end{array}$ & $\begin{array}{l}\text { mono } \\
\text { kultur }\end{array}$ & $\begin{array}{c}\text { strip } \\
\text { croping }\end{array}$ & $\begin{array}{l}\text { mono } \\
\text { kultur }\end{array}$ & $\begin{array}{c}\text { Strip } \\
\text { croping }\end{array}$ & \\
\hline A & - & 5,92 & 2,07 & 1,33 & - & - & - & - & - & - & $1,38 \mathrm{a}$ \\
\hline B & - & 5,10 & - & - & 0,30 & 0,03 & - & - & - & - & $0,73 \mathrm{c}$ \\
\hline $\mathrm{C}$ & - & 5,62 & - & - & - & - & 1,80 & 0,87 & - & - & $1,18 \mathrm{~b}$ \\
\hline D & - & 5,50 & - & - & - & - & - & - & 10,3 & 6,95 & $1,36 \mathrm{ab}$ \\
\hline $\mathrm{E}$ & 7,97 & 0,00 & - & - & - & - & - & - & - & - & $0.00 \mathrm{~d}$ \\
\hline
\end{tabular}

Keterangan: Huruf yang berbeda pada kolom yang sama menunjukkan berbeda nyata menurut Uji Berganda Duncan 5\%. A). Jagung strip cropping kacang tanah, B). Jagung strip cropping kacang hijau, C). Jagung strip cropping kedele, D). Jagung strip cropping ubi jalar, E). Jagung monokultur (kontrol)

Untuk menghasilkan 1,33 ton kacang tanah dan 5,92 ton pipilan kering jagung diperlukan lahan seluas 1,38 ha pada pertanaman jagung monokultur. Hal ini menunjukkan bahwa strip cropping jagung dengan kacang tanah lebih menguntungkan dibanding sistem tanam monokultur jagung karena lebih efisien dalam pemanfaatan lahan.

Nilai kesetaraan lahan (NKL) perlakuan B jagung strip cropping kacang hijau paling rendah tiak cukup satu hanya 0,73 dan berbeda nyata dengan empat perlakuan lainnya. Hal ini mengindikasikan bahwa sistem tanam strip cropping jagung kacang hijau hanya $0,73 \%$ dari sistem tanam jagung monokultur. Hal ini sejalan dengan pernyataan Yuwariah (2011) bahwa nilai NKL kurang dari satu tidak menguntungkan untuk pertanaman tumpangsari. Rendahnya nilai NKL jagung strip cropping kacang hijau disebabkan pertumbuhan kacang hijau mengalami masalah sehingga banyak tidak tumbuh yang berakibat produksi rendah. Dilakukan dua kali penyulaman hasilnya tetap banyak tidak tumbuh. Informasi dari petani kooperator bahwa sebelum kajian dilakukan, petani pernah tanami kacang hijau lokasi tersebut namun lebih banyak tidak tumbuh dibanding yang tumbuh. Hal ini memerlukan kajian khusus lebih lanjut tentang penyebab masalah tersebut. $\sqrt{ }$

Perlakuan D jagung strip cropping ubi jalar mempunyai nilai NKL 1,36 dan tidak berbeda nyata dengan perlakuan $\mathrm{C}$ (Tabel 5).
Nilai NKL yang tinggi pada ubi jalar karena didukurng produksi umbi yang tinggi (6,95 ton). Untuk menghasilkan 6,95 ton ubi jalar dan 5,50 ton pipilan kering jagung diperlukan lahan selus 1,36 ha untuk pertanaman jagung monokultur. Ini menggambarkan bahwa pola tanam srip cropping jagung ubi jalar lebih efisien dalam pemanfaatan lahan dibanding pola tanam monokultur jagung. Perlakuan E dengan pola tanam monokultur sebagai kontrol tidak memiliki NKL karena petani belum terbiasa dengan pola tanam ganda dengan alasan beban pekerjaan bertambah.

Nisbah Kesetaraan Lahan semua perlakuan pola strip croping memberikan nilai lebih dari satu kecuali perlakuan B jagung srtrip cropping kacang hijau mempunyai nilai NKL kurang dari satu (Tabel 5). Hal ini menggambarkan pola strip cropping lebih produktif dibanding monokultur. Sistem tanam strip cropping jagung dengan kacang - kacangan meningkatkan efisiensi pemanfaatan sumberdaya lahan meningkatkan volume dan frekwensi panen dibanding sistem tanam monokultur (Syafruddin et.al, 2010). Nilai NKL yang tinggi pada jagung strip cropping kacang tanah dan jagung strip cropping ubi jalar karena kedua komoditas tersebut (kacang tanah dan ubi jalar) produksinya lebih tinggi dibanding produksi tanaman strip lainnya (Tabel 5). Semua perlakuan strip cropping (A, C dan D) dengan nilai Nisbah Kesetaraan Lahan (NKL) lebih dari 
satu itu menguntungkan (Tabel 5). Sedang pola strip cropping jagung dengani kacang hijau mempunyai nilai NKL tidak cukup satu hanya 0,73 . Hal ini mengindikasikan bahwa pola strip cropping jagung dengan kacang hijau hanya mencapai $0,73 \%$ dari hasil pertanaman tunggal kacang hijau sehingga tidak menguntungkan untuk pertanaman strip cropping. Perlakuan pola tanam strip cropping dengan Nisbah Kesetaraan Lahan kurang dari satu tidak menguntungkan (Yuwariah, 2011).

\section{KESIMPULAN}

Perbedaan pola tanam tumpangsari dengan pola tanam strip cropping terletak pada luasan petak tanam strip cropping lebih luas dibanding petak tumpangsari. Jagung strip cropping kacang tanah memiliki indeks luas daun (ILD) paling lebar $(4,26)$, namun tidak berbeda nyata dengan perlakuan $\mathrm{B}, \mathrm{C}$ dan $\mathrm{D}$. Kecuali perlakuan $\mathrm{E}$ dengan nilai ILD terendah $(3,56)$. Jagung strip cropping kacang tanah, jagung strip cropping kedele dan jagung strip cropping ubi jalar lebih efisien serta lebih produktif dibanding monokultur yang ditunjukkan nilai kesetaraan lahan lebih dari satu. Sedangkan nilai kesetaraan lahan (NKL) tertinggi yaitu jagung strip cropping kacang tanah $(1,38)$, namun tidak berbeda nyata dengan jagung strip cropping ubi jalar $(1,36)$. Jagung strip cropping kacang hijau memiliki NKL terendah $(0,75)$ dan berbeda nyata dengan nilai NKL perlakuan lainnya. Hal ini disebabkan kurangnya populasi kacang hijau yang tumbuh.

\section{DAFTAR PUSTAKA}

Adnan, A.M. Constance Rapar dan Zubachtirodin, 2010. Deskripsi Varietas Unggul Jagung ISBN: 979-8940-08-3. Balai Penelitian Tanaman Serealia. Pusat Penelitian dan Pengembangan Tanaman Pangan. Kementerian Pertanian

Amir, A.Yulyani Fadwiwati dan Baso Aliem Lologau, 2015. Kajian Teknologi Sistem Tanam IP 300 Pada Agroekosistem Lahan Sawah Tadah Hujan di Kabupaten Takalar. Prosiding Seminar Nasional. Membangun Kedaulatan Pangan Yang Berkelanjutan. Buku I. Gorontalo, 25-26 Agustus 2015. Balai Besar Pengkajian dan Pengembangan Teknologi Pertanian. Badan Penelitian dan Pengembangan Pertanian. Kementerian Pertanian.
Amir, 2010. Laporan Hasil Kegiatan. Kajian Sistem Tanam Jagung dalam Konteks Integrasi Tanaman - Ternak. Balai Pengkajian Teknologi Pertanian Sulawesi Selatan.

Beets, W.C, 1982. Multiple Cropping and Tropical Farming Systems. Gower Publising Co.

Beets, W.C, 1982. Multiple Cropping and Tropical Farming System. Gower Pulising Company Limited. England, 156p. Dalam Syafruddin dan Suwardi, 2015. Pemanfaatan Lahan pada Tanam Sistem Legowo Jagung dengan Tumpangsari Kacang Hijau. Prosiding Seminar Nasional Serealia.

Belel, M.D., R.A. Halim., M.Y. Rafii, and H.M. Saad. 2014. Inercropping of corn with some selected legumes for imroved forage production . A .Reviuw. J.Agric. Sci. 6(3):48-62

BPS, 2010. Sulawesi Selatan Dalam Angka. Badan Pusat Statistik Provinsi Sulawesi Selatan

BPS, 2013. Laporan Survey Lahan Pertanian Sulawesi Selatan (SP-LAHAN). Biro Pusat Stastik Sulawesi Selatan.

Fadhly, A.F dan Djamaluddin, 1993. Perkembangan Produksi dan Teknologi Peningkatan Hasil Jagung di Sulawesi Selatan. Prosiding Simposium Penelitian Tanaman Pangan. Kinerja Penelitian Tanaman Pangan. Buku 4. Hal.10841094. Pusat Penelitian Tanaman Pangan. Badan Litbang Pertanian

Fik dan J.J. Hanway, 1996. Leaf area in relation to yield corn grain. Agron.J 58:16-18. Dalam Amir, A. Yulyani Fadwiwati dan Baso Alliem Lologau, 2015. Kajian Teknologi Sistem Tanam IP300 Pada Agroekosistem Lahan Sawah Tadah Hujan di Kabupaten Takalar. Prosiding Seminar Nasional Membangun Kedaulatan Pangan Yang Berkedaulatan. Buku 1. Gorontalo, 25-26 Agustus 2015. Balai Besar Pengkajian dan Pengembangan Teknologi Pertanian. Badan Litbang Pertanian.

Gliessman. S.R. 1985. Multiple Cropping Systems: A basis for developing an alternative agriculture. P. 69-83 in T.C. Edens, C. Fridgen dan S.L. Battlefield (editor). 
Horisson-Murray, R.S, dan R. Lal, 1979. Soil physical conditions and plant growth. John Wiley and Sons. New York.

Kasryno, F.2002. Perkembangan Produksi dan Konsumsi Jagung Dunia selama empat dekade yang lalu dan implikasinya bagi Indonesia. Paper disampaikan dalam seminar sehari pada acara Agribisnis Jagung di Bogor.

S.Sri, 2016. Penentuan Tingkat Masak Benih Jagung. Makalah disampaikan pada Lokakarya Perbenihan Jagung di Balai Penelitian Serealia. Maros, 20-23 November.

Stoskops, N. 1981. Understading Crop Production. Reston Pub. Virginia. P.97109 Dalam Roy Efendi dan Suwardi, 2010. Respon Tanaman Jagung Hibrida dan Kepadatan Populasi. Prosiding Pekan Serealia Nasional. ISBN : 978879-8940-29-3. P260-268.

Subandi, dan I. Manwan. 1990. Teknologi dan Peningkatan Produksi Jagung di
Indonesia. Pusat Penelitian dan Pengembangan Tanaman Pangan. Bogor Suwardi dan Syafruddin, 2015. Pemanfaatan Lahan pada Sistem Tanam Legowo Jagung dengan Tumpangsari Kacang Hijau. Prosiding Seminar Nasional Serealia.

Syafruddin, I. Mado dan Idris, 2010. Perbedaan Waktu Tanam Kacang Hijau dalam Pertanaman Jagung. Jurnal Agrosistem. Vol. 6 No. 1. 1-7.

Trenbath, B.R, 1986. Resource use by intercross. Dalam C.A. Francis (editor)

Yuwariah. Y; D. Ruswandi; A.W. Irwan. 2017. Pengaruh Pola Tanam Tumpangsari Jagung dan Kedele Terhadap Pertumbuhan dan Hasil Jagung Hibrida dan Evaluasi Tumpang sari di Arjasari. Kabupaten Bandung. Jurnal Kultivasi. Vol.16. Desember.

Yuariah. Y, 2011. Peran Tanam Sela dan Tumpangsari Bersisipan Berbasis Padi Gogo Toleran Naungan. Giratuna. Bandung. 